\title{
A study on the effectiveness of coping with test anxiety program based on cognitive-behavioral approach
}

\author{
Fulya Türk ${ }^{1}$, Ayşe Nur Katmer ${ }^{2}$ \\ ${ }^{1}$ Departement Guidance and Psychological Counseling, Gaziantep University, Turkey \\ ${ }^{2} 15$ Temmuz Şehitleri Secondary School, Turkey
}

\begin{tabular}{l} 
Article Info \\
\hline Article history: \\
Received Sep 5, 2019 \\
Revised Nov 19, 2019 \\
Accepted Nov 29, 2019 \\
\hline
\end{tabular}

\section{Keywords:}

Adolescent

Cognitive-bahavioral approach Irrational beliefs

Test Anxiety

\begin{abstract}
The purpose of this study is to examine the impact of the program for coping with test anxiety based on the cognitive-behavioral approach on the levels of test anxiety, irrational thoughts, coping levels and academic self-efficacy perceptions of adolescents in the 8th grade. The study was performed as a semi-experimental study based on pre-test and post-test model with an experimental group and a control group. There were 32 students studying in the 8th grade in Kilis during the 2018-2019 school year participated in the study. While a seven-session Coping with Test Anxiety program based on Cognitive-Behavioral approach was applied to the students in the experimental group, no study was conducted with the control group. The Mann-Whitney U Test, Friedman Test, and Wilcoxon Signed-Rank Test were used in the analyses of data obtained from the study. According to study results, it can be said that the program for coping with test anxiety based on the cognitive-behavioral approach was significantly effective in the levels of test anxiety, irrational beliefs and active and avoidant coping levels of the adolescents while it was not effective in academic self-efficacy perceptions and negative avoidant coping levels.
\end{abstract}

Copyright (c) 2019 Institute of Advanced Engineering and Science. All rights reserved.

\section{Corresponding Author:}

Fulya Türk,

Departement Guidance and Psychological Counseling

Gaziantep University,

Üniversite Bulvarı 27310 Şehitkamil - Gaziantep, Turkey

Email: fulyaturk@gantep.edu.tr

\section{INTRODUCTION}

Test anxiety is a common problem of adolescents negatively affecting their academic lives and personal well-being levels. Particularly the exams with central selection and elimination methods affecting high school and university selections of students create substantial pressure on both adolescents and their families. For that reason, this is an important topic that has been studied for many years. Test anxiety is defined as emotional, behavioral, physiological reactions that accompany possible negative consequences in an upcoming test or exam [1]. Test anxiety causes students to have poor performance [2]. Additionally, several studies demonstrate that test anxiety is associated with the academic success of students and predicts academic success [3-6]. Test anxiety is directly associated with fear of negative evaluation, self-esteem, and other forms of anxiety [2]. In their test anxiety model based on a biopsychosocial model, Lowe et al. [7] emphasized that the intelligence, social-emotional functioning, state anxiety, study skills, and habits and academic self-efficacy play a vital role in perceiving an upcoming exam as a threat. The perceived evaluation threat causes test anxiety depending on the negative peer and parent evaluations, the idea of loss of status, and the importance of the exam. Cognitive, behavioral and physiological factors of test anxiety also affect the performance. It is known that test anxiety has two primary sources. These are worry (cognitive concerns about one's performance) and emotionality (autonomic reactions to the exam). In case of the presence of both 
components at the same time, test anxiety would appear to be both cognitive (worry) and behavioral (emotionality) [2]. If the focus of test anxiety is the individual's fear of evaluation, the situation has two components as defined by Liebert and Morris [8]. A cognitive component is cognitive activities, including the individual's conceptions regarding the test and the test situation. Thoughts of an anxious child who is expecting to show poor performance in a test include the ideas that can be characterized by negative comparisons to others, doubts about own skills and negative views on the consequences of poor test performance. The second component of test anxiety is emotionality which is a physiological component of test anxiety. It can be manifested in the individual as high heart rate, muscle tension, perspiration, feeling sick and tremors. There are many effective factors in the formation of test anxiety; however, they are not effective at the same level and time. Although specific emotive reactions accompany all evaluation situations, what will shape the reactions of an individual in a test situation is past experiences and beliefs [9].

One of the frequently used approaches in coping with test anxiety is the cognitive-behavioral approach. The cognitive-behavioral approach emphasizes cognitive functions in psychological problems. If expectations and beliefs in cognitive structure, which determines a person's outlook on the world and interpretations, are distorted or dysfunctional, the individual starts to have problems. Accordingly, problems of people are a falsification of truth in consequence of incorrect premises and evaluations on a larger scale [10]. In this approach, most reactions of adolescents before and during an exam and their attitude towards, interpretation and sense-making way of the exam are very distant from the real purpose of the exam. The adolescent believes that his/her achievement level in an exam would reflect his/her value as a person [10]. Therefore, the most critical element in the cognitive-behavioral approach is addressing the adolescent's thoughts. McDonald [9] also emphasized that beliefs are one of the two most essential elements that shape the reactions of an individual to test the situation. Irrational beliefs, such as considering an exam dangerous or frightening, are essential in the occurrence of test anxiety and is one of the most common problems among students. Considering the exam a dangerous situation, being constantly preoccupied with the moment of the exam and things to happen after the exam, as well as having concerns in this regard create test anxiety. Another irrational belief is the adolescents' beliefs using modals of necessity (i.e., I must always be successful.) [11]. Typical thoughts of individuals who have high levels of cognitive test anxiety are: Comparing self-performance to peers, considering the consequences of failure, low levels of confidence in performance, excessive worry over evaluations, worrying about causing sorrow for their parents, feeling unprepared for the exam, and loss of self-worth [12]. Hembree [2] emphasized that a cognitive factor of test anxiety was consistently associated with poor performance. Therefore, it is thought that the cognitivebehavioral approach might be effective in decreasing both cognitive and emotional factors in reducing test anxiety. Additionally, as CBT emphasizes cognitions, interventions concerning test anxiety will be based on recognizing and changing non-functional thoughts. As a matter of fact, the studies reveal a relationship between test anxiety and irrational beliefs [13, 14]. Furthermore, Güler and Çakır [14] underlined that psychological counselors should change irrational beliefs while working with students coping with test anxiety.

In a meta-analysis study on test anxiety, Ergene [15] demonstrated that the most effective approach was the integration of cognitive-behavioral approach and skill-oriented approaches. It was also shown that the format integrating individual and group studies was more effective, and individual counseling was the least effective method. In a study compiling their ten-year study on test anxiety, Von Der Embse, Barterian, and Segool [16] emphasized that techniques including feedback, behavioral therapy, cognitive-behavioral therapy and mixed approaches demonstrated favorable results. Given that test anxiety is an important stressful event in the lives of adolescents, different coping strategies are used to deal with this problem. In a program in which these strategies are adopted in the cognitive-behavioral approach, it is thought that how they will be affected by cognitive restructuring is essential. Spirito, Stark and Tyc [17] grouped the adolescents' coping strategies into three categories as active, avoidant and negative. Active strategies include problem solving, emotion regulation, social support and cognitive restructing. Avoidant strategies are, distract, social remove and wish fulfillment thinking. Although negative strategies are self-criticism and blaming others .Thus, it is thought that how such strategies would progress with a program based on the cognitive-behavioral approach will contribute to the relevant literature. Önen [18] also emphasized in their study that individuals with higher adaptive coping skills had lower test anxiety while those using avoidant strategy had higher test anxiety. Therefore, it is thought that coping skills should be taken into consideration while working on test anxiety since coping strategies used by adolescents in coping with test anxiety affect the anxiety itself. Academic self-efficacy involves not an individual's physical or psychological properties or personal qualities, but the capacity of executing an academic duty [19-20]. A negative correlation between the perception of academic self-efficacy and test anxiety is also seen in some studies [3-21]. For that reason, it is considered necessary to intervene in an adolescent's perceptions and beliefs about academic self-efficacy through the cognitive-behavioral approach. 
Ergene [15] stated that the studies on decreasing test anxiety were performed mainly on university students. Similarly, in their study on the effectiveness of test anxiety interventions for children and adolescents, Von Der Embse, Barterian, and Segool [16] emphasized the few studies on elementary and secondary school students. In particular, it seems essential to implement test anxiety programs for adolescents because of the central exams during secondary and high school education in Turkey. In addition, when the literature was examined, there is no study examining the effect of cognitive-behavioral approachbased test anxiety program, exam anxiety and students' academic self-efficacy, coping skills and irrational beliefs together. In this context, the purpose of this study is to examine the impact of the program for coping with test anxiety based on the cognitive-behavioral approach on the levels of test anxiety, irrational thoughts, coping levels and academic self-efficacy perceptions of adolescents in the 8th grade.

\section{RESEARCH METHOD}

\subsection{Study design}

This research is an experimental study with an experimental group and a control group. A 3x2 splitplot, factorial (mixed), semi-experimental design with pre-test and post-test measure, and an experimental group and a control group was used in the study [22].

\subsection{Study group}

In order to determine experimental and control groups, the Test Anxiety Scale for Children was applied to 120 students in the 8th grade of a state secondary school in Kilis city center during the 2018-2019 school year. The students were randomly distributed into experimental and control groups depending on their scores on the scale.

The second author works as a psychological counselor at the school where conducted this research. Thus, it was observed that none of the members in the control and experimental group received training or support related to exam anxiety, academic self-efficacy, coping skills, and irrational beliefs during the study.

\subsection{Data collection tools}

Test Anxiety Scale for Children, Academic Self-Efficacy Scale, Individual Thoughts Scale, and Adolescent Coping Scale were used in the study.

Test Anxiety Scale for Children: Test Anxiety Scale for Children was first developed by Wren and Benson [23] to recognize and decrease or even prevent test anxiety during the childhood period when it first occurs. The scale was adapted to Turkish language by Aydin and Bulgan [24]. The 30-item scale is in fourpoint Likert type. It is understood that the level of test anxiety increases as the score goes up and decreases as the score goes down. The scale items measure three sub-dimensions, i.e. Thoughts (Items no. 1, 5, 6, 11, 13, 15, 16, 19, 21, 24, 27, and 29), Off-Task Behaviors (Items no. 3, 7, 12, 14, 18, 22, 26 and 30) and Autonomic Reactions (Items no. 2, 4, 8, 10, 17, 20, 23, 25 and 28). The overall test anxiety score is obtained by summing scores from scale items.In reliability analyses of the scale, Cronbach's Alpha value was found as .82 for Thoughts subscale, .70 for Off-Task Behaviors subscale, .75 for Autonomic Reactions subscale and the overall Cronbach's Alpha value was .88 [24].

Academic Self-Efficacy Scale: The Academic Self-Efficacy Scale was developed to measure the level of self-efficacy, which is one of the factors influencing a student's success. The scale was first developed by Morgan and Jinks [25] and adapted to Turkish by Öncü [26]. The scale is comprised of three subscales and 21 items, i.e., skill subscale (11 items), environment subscale (seven items), and education quality subscale (three items). Seven items (4, 5, 15, 19, 23, 24, and 28) are scored reversely. The Academic Self-Efficacy Scale was applied to students at an interval of three weeks to determine retest reliability. The Pearson Product-Moment Correlation coefficient between the scores obtained from two applications was found as .80. The estimated Cronbach's Alpha coefficients with respect to homogeneity of the scale and subscales were found as .81 for the overall scale, .86 for the first subscale, .71 for the second subscale and 51 for the third subscale. Results obtained for the validity and reliability of the 21-item Academic Self-Efficacy Scale show that the scale is a source that can be used for evaluating academic self-efficacy of students [26].

Individual Thoughts Scale: The Individual Thoughts Scale was developed to measure the irrational beliefs of students in the first stage of adolescence. The scale is comprised of three subscales and 21 items, i.e. success subscale (1st, 3rd, 6th, 7th, 10th, 13th, 16th and 19th items), comfort subscale (5th, 8th, 9th, 14th, 17 th, 20th and 21st items) and respect subscale (2nd, 4th, 11th, 12th, 15th and 16th items). Reliability coefficient regarding the score invariance obtained by implementing Individual Thoughts Scale twice at an interval of three weeks was found as .82 for the overall scale, .84 for Demand for Success subscale, .75 for 
Demand for Comfort subscale and .67 for Demand for Respect subscale. Internal consistency coefficient (Cronbach's Alpha) of the scale was .71 for the overall score [27].

Adolescent Coping Scale: The Adolescent Coping Scale was developed to understand how individuals cope with stressful life events and the process of managing psychological, social, emotional, cognitive and educational problems, and adapting to these processes. The scale was first developed by Spirito, Stark and Williams [28]. It was adapted to Turkish by Bedel, Iş1k and Hamarta [29]. The scale is comprised of three subscales and 11 items, i.e., active coping (3rd, 6th, 8th, and 10th items), negative coping (4th, 5th, and 7th items) and avoidant coping (1st, 2nd, 9th, and 11th items). The scale is processed based on the subscales rather than the total score. Internal consistency coefficient of the Adolescent Coping Scale was found as .72 for Active Coping, .70 for Avoidant Coping, and .65 for Negative Coping. Test-retest reliability coefficient evaluated at an interval of three weeks was found as $r=.66$ for Active Coping, $r=.61$ for Avoidant Coping and $r=.76$ for Negative Coping. The results show that Turkish version of Adolescent Coping Scale is a valid and reliable measuring tool that can be used to evaluate coping approaches of students in the 7 th to 11 th grade [29].

Coping with Test Anxiety Program: This study takes seven-session coping with test anxiety program developed by Olgun [30] as a reference. The necessary adaptation was performed in line with the characteristics and needs of schools and students. Based on the cognitive-behavioral approach and application, the program aims to develop rational thoughts and new perception forms instead of irrational thoughts to decrease anxiety. It also teaches techniques such as muscle relaxation, imagination, and correct breathing, which have an essential place in decreasing distress and anxiety. The studied topics include the definition of anxiety; the difference between anxiety and fear; differentiating an individual's reactions to an event as emotion, thought and behavior; differentiating the reactions to an event as rational belief and irrational belief; relaxation exercise; developing positive emotions; the use of time and setting an objective.

\subsection{Process}

In order to determine experimental and control groups, the Test Anxiety Scale for Children was applied to 120 students in the 8th grade of a state secondary school in Kilis city center during the 2018-2019 school year. The students were selected based on scores from the scale, with 16 students being randomly assigned to the experimental group and 16 students to the control group. The second investigator implemented the psychoeducation program. The students in the experimental group were informed of the psychoeducation program. The students were assured that the implementation was completely based on fundamental principles of psychoeducation groups such as volunteering, confidentiality, and respect. The program for coping with test anxiety was applied only to the students in the experimental group. A student in the experimental group left the study due to a school change during the third session of the implementation. Therefore, the experimental group continued the program with 15 students. A post-test was applied to both groups after the implementation. Monitoring measurements were completed five months after the post-test. Following the monitoring measurements, voluntary and willing students in the control group were included in the program for coping with test anxiety.

\subsection{Data analysis}

In this study, non-parametric tests were preferred due to few study groups and inability to meet normality assumptions on some scales. The Mann-Whitney U Test, Friedman Test and Wilcoxon SignedRank Test were used to determine the difference between mean values of rank obtained from pre-, post- and follow-up test measurements of experimental and control groups, whether the difference between mean rank values of scores obtained from pre-, post- and follow-up test measurements was significant or not, and between which measurements the detected difference was significant, respectively. Additionally, the $\mathrm{p}$ value, as well as effect size, were assessed in the study. Effect size is the unit of correlation strength between two variables [31] Effect size intervals have small, medium, and large effect power if $r<0.20,20<r<50$ and $r>50$, respectively [32].

\section{RESULTS AND DISCUSSION}

The purpose of this study is to examine the impact of the program for coping with test anxiety based on the cognitive-behavioral approach on test anxiety, academic self-efficacy, coping strategies, and cognitive thoughts of adolescents. The arithmetic mean values and standard deviations of the scores obtained before and after the procedure by experimental and control groups from Test Anxiety Scale for Children, Academic Self-Efficacy Scale, Individual Thoughts Scale, and Adolescent Coping Scale were primarily calculated in the study. The values obtained are shown in Table 1. 
Table 1. Descriptive results of pre- and post-test TA, ASES, ITS and ACS scores of experimental and control groups

\begin{tabular}{ccccccc}
\hline \multicolumn{2}{c}{\begin{tabular}{c} 
Measures \\
\multicolumn{2}{c}{ Groups }
\end{tabular}} & \multicolumn{2}{c}{ Pre-Test } & \multicolumn{2}{c}{ Post-Test } \\
\multirow{2}{*}{ TA } & Experimental & 15 & 83.93 & 9.59 & 63.87 & 3.87 \\
& Control & 16 & 89.18 & 11.43 & 88.25 & 3.79 \\
\multirow{2}{*}{ ASES } & Experimental & 15 & 57.80 & 8.06 & 56.27 & 5.19 \\
& Control & 16 & 55.40 & 10.23 & 58.25 & 8.35 \\
& Experimental & 15 & 62.13 & 15.45 & 41.87 & 9.73 \\
ITS & Control & 16 & 64.19 & 12.05 & 67.13 & 15.41 \\
& Experimental & 15 & 7.73 & 1.79 & 10.47 & .99 \\
ACS-Active & Control & 16 & 7.44 & 2.56 & 6.88 & 2.03 \\
& Experimental & 15 & 6.47 & 2.07 & 5.80 & 1.37 \\
ACS-Avoidant & Control & 16 & 7.63 & 1.96 & 7.40 & 2.44 \\
& Experimental & 15 & 2.80 & 1.21 & 2.80 & 1.08 \\
ACS-Negative & Control & 16 & 2.94 & 1.95 & 3.25 & 2.08 \\
\hline
\end{tabular}

TA: Test Anxiety; ASES: Academic Self-Efficacy Scale, ITS: Individual Thoughts

Scale, ACS: Adolescent Coping Scale

Table 1 shows that the experimental group had a greater decrease in mean scores from the pre- and post-test Test Anxiety Scale than the control group. There is no significant difference between experimental and control groups in terms of pre- and post-test scores in the Academic Self-Efficacy Scale. It is seen that the experimental group had a more significant increase in mean scores from pre- and post-test Individual Thoughts Scale than the control group. In the Active subscale of Adolescent Coping Scale, it is seen that the experimental group had a greater increase in mean scores from pre- and post-test than the control group. While the greater decrease is seen in mean pre- and post-test scores of the experimental group than the control group in Avoidant subscale of the Adolescent Coping Scale, there is no large difference between the experimental and control groups in pre- and post-test scores in Negative subscale of the Adolescent Coping Scale.

An analysis was made by the Mann-Whitney U test to determine whether there was a significant difference between pre-test, post-test and follow-up test scores of students in the experimental and control groups in Test Anxiety Scale for Children, Academic Self-Efficacy Scale, Individual Thoughts Scale, and Adolescent Coping Scale. Data from the analysis results is provided in Table 2.

Table 2. Mann-Whitney U Test results

\begin{tabular}{|c|c|c|c|c|c|c|}
\hline \multirow{2}{*}{$\begin{array}{c}\text { Measures } \\
T A\end{array}$} & \multicolumn{2}{|c|}{ Experimental } & \multicolumn{2}{|c|}{ Control } & \multirow[t]{2}{*}{$\mathrm{U}$} & \multirow[t]{2}{*}{$\mathrm{p}$} \\
\hline & Mean Rank & Sum of Ranks & Mean Rank & Sum of Ranks & & \\
\hline Pre-Test & 13.63 & 204.50 & 18.22 & 291.50 & 84.50 & .16 \\
\hline Post-Test & 10.17 & 152.50 & 21.47 & 343.50 & 32.50 & .00 \\
\hline Follow-Up & 10.67 & 160.00 & 21.00 & 336.00 & 40.00 & .00 \\
\hline Measures & \multicolumn{2}{|c|}{ Experimental } & \multicolumn{2}{|c|}{ Control } & $\mathrm{U}$ & $\mathrm{p}$ \\
\hline ASES & Mean Rank & Sum of Ranks & Mean Rank & Sum of Ranks & & \\
\hline Pre-Test & 16.00 & 240.00 & 15.00 & 225.00 & 105.00 & .75 \\
\hline Post-Test & 14.13 & 212.00 & 17.75 & 284.00 & 92.00 & .27 \\
\hline Follow-Up & 15.23 & 228.50 & 16.72 & 267.50 & 108.50 & .65 \\
\hline Measures & \multicolumn{2}{|c|}{ Experimental } & \multicolumn{2}{|c|}{ Control } & $\mathrm{U}$ & $\mathrm{p}$ \\
\hline ITS & Mean Rank & Sum of Ranks & Mean Rank & Sum of Ranks & & \\
\hline Pre-Test & 15.43 & 231.50 & 16.53 & 264.50 & 111.50 & .74 \\
\hline Post-Test & 9.13 & 137.00 & 22.44 & 359.00 & 17.00 & .00 \\
\hline Follow-Up & 9.23 & 138.50 & 22.34 & 357.50 & 18.50 & .00 \\
\hline Measures & \multicolumn{2}{|c|}{ Experimental } & \multicolumn{2}{|c|}{ Control } & $\mathrm{U}$ & $\mathrm{p}$ \\
\hline ACS-Active & Mean Rank & Sum of Ranks & Mean Rank & Sum of Ranks & & \\
\hline Pre-Test & 16.80 & 252.00 & 15.25 & 244.00 & 108.00 & .63 \\
\hline Post-Test & 23.03 & 345.50 & 9.41 & 150.50 & 14.50 & .00 \\
\hline Follow-Up & 22.57 & 338.50 & 9.84 & 157.50 & 21.50 & .00 \\
\hline Measures & \multicolumn{2}{|c|}{ Experimental } & \multicolumn{2}{|c|}{ Control } & $\mathrm{U}$ & $\mathrm{p}$ \\
\hline ACS-Avoidant & Mean Rank & Sum of Ranks & Mean Rank & Sum of Ranks & & \\
\hline Pre-Test & 13.33 & 200.00 & 18.50 & 296.00 & 80.00 & .11 \\
\hline Post-Test & 12.07 & 181.00 & 18.93 & 284.00 & 61.00 & .03 \\
\hline Follow-Up & 11.73 & 176.00 & 20.00 & 320.00 & 56.00 & .01 \\
\hline Measures & \multicolumn{2}{|c|}{ Experimental } & \multicolumn{2}{|c|}{ Control } & $\mathrm{U}$ & $\mathrm{p}$ \\
\hline ACS-Negative & Mean Rank & Sum of Ranks & Mean Rank & Sum of Ranks & & \\
\hline Pre-Test & 15.97 & 239.50 & 16.03 & 2256.50 & 119.50 & .98 \\
\hline Post-Test & 14.73 & 221.00 & 17.19 & 275.00 & 101.00 & .44 \\
\hline Follow-Up & 13.50 & 202.50 & 18.34 & 293.50 & 82.50 & .13 \\
\hline
\end{tabular}

Int. J. Eval. \& Res. Educ. Vol. 8, No. 4, December 2019: 666 - 675 
In Table 2, no significant difference was found between pre-test scores of test anxiety $[\mathrm{U}(31)=$ 84.50, p>.05], academic self-efficacy $[\mathrm{U}(31)=105.00, \mathrm{p}>.05]$, irrational beliefs $[\mathrm{U}(31)=111.50, \mathrm{p}>.05]$, active coping $[\mathrm{U}(31)=108.00, \mathrm{p}>.05]$, avoidant coping $[\mathrm{U}(31)=80.00, \mathrm{p}>.05]$ and negative coping $[\mathrm{U}(31)=$ $119.50, \mathrm{p}>.05]$ before the procedure.

As seen in Table 2, a significant difference was found between post-test scores of test anxiety $[\mathrm{U}(31)=32.50, \mathrm{p}<.05]$, irrational beliefs $[\mathrm{U}(31)=17.00, \mathrm{p}<.05]$, active coping $[\mathrm{U}(31)=14.50, \mathrm{p}<.05]$ and avoidant coping $[\mathrm{U}(31)=61.00, \mathrm{p}<.05]$. No significant differentiation was seen in academic self-efficacy $[\mathrm{U}(31)=92.00, \mathrm{p}>.05]$ and negative coping $[\mathrm{U}(31)=101.00, \mathrm{p}>.05]$ variables.

When Table 2 is examined, a significant difference was found between follow-up test scores of test anxiety $[\mathrm{U}(31)=40.00, \mathrm{p}<.05]$, irrational beliefs $[\mathrm{U}(31)=18.50, \mathrm{p}<.05]$, active coping $[\mathrm{U}(31)=21.50, \mathrm{p}<$ $.05]$ and avoidant coping $[\mathrm{U}(31)=56.00, \mathrm{p}<.05]$. No significant differentiation was seen in academic selfefficacy $[\mathrm{U}(31)=108.50, \mathrm{p}>.05]$ and negative coping $[\mathrm{U}(31)=82.50, \mathrm{p}>.05]$ variables.

The Friedman Test was used to examine whether there were differences between the three measurements as a result of the in-group comparison of pre-test, post-test, and follow-up test scores of the experimental and control groups. In case of a difference between measurements, the Wilcoxon Signed-Rank Test was used to determine which measurement had a difference. The results of the Friedman test are given in Table 3.

As seen in Table 3, there is no significant difference between mean scores of the control group from pre-test, post-test, and follow-up measurements in all subscales of TA, ASES, ITS, and ACS. A significant difference was found between mean scores of the experimental group from pre-test, post-test and follow-up measurements in test anxiety scale $(p<0.00)$, individual thoughts scale $(p<0.00)$ and active subscale of coping scale $(p<0.00)$. On the contrary, a significant difference was not found between mean scores of the experimental group from pre-test, post-test and follow-up measurements in academic self-efficacy scale ( $p>0.27)$ and avoidant ( $p>0.14)$ and negative $(p>0.87)$ subscales of coping scale. The Wilcoxon SignedRank Test was used to find the source of difference between mean scores from pre-test, post-test, and followup measurements in the experimental group. The results of the Wilcoxon Signed-Rank Test are provided in Table 4.

When Table 4 is examined, a significant difference is observed between pre- and post-test scores of the experimental group in TA $(\mathrm{z}=-3.41, \mathrm{p}<.05, \mathrm{r}=-0.88)$, ASES $(\mathrm{z}=-3.18, \mathrm{p}<.05, \mathrm{r}=-0.82)$ and ACS-Active $(\mathrm{z}=-3.32, \mathrm{p}<.05, \mathrm{r}=-0.85)$ scales. In addition, it is seen that there is a large impact value on test anxiety, irrational beliefs, and active coping. No significant differentiation is seen in ASES $(\mathrm{z}=-.19, \mathrm{p}>.05, \mathrm{r}=0.04)$, ACS-Avoidant $(\mathrm{z}=-.81, \mathrm{p}>.05, \mathrm{r}=-0.02)$ and ACS-Negative $(\mathrm{z}=-.11, \mathrm{p}>.05, \mathrm{r}=-0.02)$ variables.

Consequently, it can be said that coping with test anxiety program based on cognitive-behavioral approach decreases test anxiety levels and irrational beliefs of adolescents; is effective in increasing active coping style and decreasing avoidant coping style; and that it is a long-term effect. On the contrary, it can be said that coping with test anxiety program is not effective in negative coping skills and academic selfefficacy perceptions of adolescents.

It is seen in this study that the cognitive-behavioral approach is an effective method in decreasing test anxiety of adolescents. This conclusion is consistent with the studies in the literature [15, 33-37]. It is seen in the studies on test anxiety that grounding on cognitive-behavioral approach might be effective in decreasing test anxiety. Ulusoy, Yavuz, Esen, Umut, and Karatepe [38] examined the effectiveness of only cognitive group therapy on test anxiety and emphasized that using cognitive and behavioral techniques together could be more effective. It is thought that test anxiety levels of adolescents might be decreased by elaborating cognitive dimension of the test anxiety in programs for test anxiety based on the cognitivebehavioral approach and including the emotionality factor in the process with behavioral techniques through relaxation and breathing exercises and the assessment of time, method and working habits. 
Table 3. Results of the Friedman test

\begin{tabular}{|c|c|c|c|c|c|}
\hline TA & Measures & Xsıra & $x^{2}$ & sd & $\mathrm{p}$ \\
\hline \multirow[t]{3}{*}{ Experimental } & Pre-test & 2.93 & & & \\
\hline & Post-test & 1.33 & 21.52 & 2 & .00 \\
\hline & Follow-Up & 1.73 & & & \\
\hline \multirow[t]{3}{*}{ Control } & Pre-test & 2.19 & & & \\
\hline & Post-test & 2.03 & 1.41 & 2 & .49 \\
\hline & Follow-Up & 1.78 & & & \\
\hline ASES & Measures & $\mathrm{X}_{\text {srra }}$ & $x^{2}$ & $\mathrm{Sd}$ & $\mathrm{p}$ \\
\hline \multirow[t]{3}{*}{ Experimental } & Pre-test & 2.03 & & & \\
\hline & Post-test & 2.27 & 2.61 & 2 & .27 \\
\hline & Follow-Up & 1.70 & & & \\
\hline \multirow[t]{3}{*}{ Control } & Pre-test & 1.60 & & & \\
\hline & Post-test & 2.07 & 4.13 & 2 & .13 \\
\hline & Follow-Up & 2.33 & & & \\
\hline ITS & Measures & $\mathrm{X}_{\text {srra }}$ & $x^{2}$ & sd & $\mathrm{p}$ \\
\hline \multirow[t]{3}{*}{ Experimental } & Pre-test & 2.77 & & & \\
\hline & Post-test & 1.73 & 14.10 & 2 & .00 \\
\hline & Follow-Up & 1.50 & & & \\
\hline \multirow[t]{3}{*}{ Control } & Pre-test & 2.19 & & & \\
\hline & Post-test & 1.97 & 1.00 & 2 & .61 \\
\hline & Follow-Up & 1.84 & & & \\
\hline ACS-Active & Measures & $\mathrm{X}_{\text {sira }}$ & $x^{2}$ & $\mathrm{sd}$ & $\mathrm{p}$ \\
\hline \multirow[t]{3}{*}{ Experimental } & Pre-test & 2.30 & & & \\
\hline & Post-test & 2.53 & 17.18 & 2 & .00 \\
\hline & Follow-Up & 1.17 & & & \\
\hline \multirow[t]{3}{*}{ Control } & Pre-test & 2.06 & & & \\
\hline & Post-test & 1.97 & 0.11 & 2 & .95 \\
\hline & Follow-Up & 1.97 & & & \\
\hline ACS- Avoidant & Measures & $\mathrm{X}_{\text {srra }}$ & $x^{2}$ & sd & $\mathrm{p}$ \\
\hline \multirow[t]{3}{*}{ Experimental } & Pre-test & 2.37 & & & \\
\hline & Post-test & 1.83 & 3.87 & 2 & .14 \\
\hline & Follow-Up & 1.80 & & & \\
\hline \multirow[t]{3}{*}{ Control } & Pre-test & 1.90 & & & \\
\hline & Post-test & 2.00 & .35 & 2 & .84 \\
\hline & Follow-Up & 2.10 & & & \\
\hline ACS-Negative & Measures & $\mathrm{X}_{\text {srra }}$ & $x^{2}$ & $\mathrm{sd}$ & $\mathrm{p}$ \\
\hline \multirow[t]{3}{*}{ Experimental } & Pre-test & 1.90 & & & \\
\hline & Post-test & 2.03 & .29 & 2 & .87 \\
\hline & Follow-Up & 2.07 & & & \\
\hline \multirow{3}{*}{ Control } & Pre-test & 1.81 & & & \\
\hline & Post-test & 1.91 & 2.33 & 2 & .31 \\
\hline & Follow-Up & 2.21 & & & \\
\hline
\end{tabular}

TA: Test Anxiety; ASES: Academic Self-Efficacy Scale, ITS: Individual Thoughts Scale, ACS: Adolescent Coping Scale

Table 4. Results of the Wilcoxon Signed-Rank test

\begin{tabular}{|c|c|c|c|c|c|c|c|}
\hline & Group & $\mathrm{N}$ & Mean Rank & Sum of Ranks & $\mathrm{z}$ & $\mathrm{p}$ & $\mathrm{r}$ \\
\hline \multirow{3}{*}{$\begin{array}{c}\text { TA } \\
\text { (pretest-posttest) }\end{array}$} & Negative Ranks & 15 & 8.00 & 120.00 & & & \\
\hline & Positive Ranks & 0 & .00 & .00 & -3.41 & .00 & -0.88 \\
\hline & Ties & 0 & & & & & \\
\hline \multirow{3}{*}{$\begin{array}{c}\text { ASES } \\
\text { (pretest-posttest) }\end{array}$} & Negative Ranks & 6 & 9.25 & 55.50 & & & -0.04 \\
\hline & Positive Ranks & 8 & 6.19 & 49.50 & -.19 & .85 & \\
\hline & Ties & 1 & & & & & \\
\hline \multirow{3}{*}{$\begin{array}{c}\text { ITS } \\
\text { (pretest-posttest) }\end{array}$} & Negative Ranks & 14 & 8.29 & 116.00 & & & \\
\hline & Positive Ranks & 1 & 4.00 & 4.00 & -3.18 & .00 & -0.82 \\
\hline & Ties & 0 & & & & & \\
\hline \multirow{3}{*}{$\begin{array}{c}\text { ACS-Active } \\
\text { (pretest-posttest) }\end{array}$} & Negative Ranks & 0 & .00 & .00 & & & \\
\hline & Positive Ranks & 14 & 7.5 & 105.00 & -3.32 & .00 & -0.85 \\
\hline & Ties & 1 & & & & & \\
\hline \multirow{3}{*}{$\begin{array}{l}\text { ACS-Avoidant } \\
\text { (pretest-posttest) }\end{array}$} & Negative Ranks & 8 & 5.25 & 42.00 & & & \\
\hline & Positive Ranks & 3 & 8.00 & 24.00 & -.81 & .42 & -0.02 \\
\hline & Ties & 4 & & & & & \\
\hline \multirow{3}{*}{$\begin{array}{l}\text { ACS-Negative } \\
\text { (pretest-posttest) }\end{array}$} & Negative Ranks & 7 & 6.71 & 47.00 & & & \\
\hline & Positive Ranks & 6 & 7.33 & 44.00 & -.11 & .92 & -0.02 \\
\hline & Ties & 2 & & & & & \\
\hline
\end{tabular}

TA: Test Anxiety; ASES: Academic Self-Efficacy Scale, ITS: Individual Thoughts Scale, ACS: Adolescent Coping Scale

Since the cognitive-behavioral approach works with cognition and cognition plays a crucial role in test anxiety, it is thought that the decrease in irrational beliefs is important. Moreover, Güler and Çakır [14] 
emphasized in their study that irrational beliefs were the most important predictor of test anxiety. Thus, it is seen that the emphasis on cognitions, demonstrating the relationship of thoughts with emotions and behaviors and the impact thereof, and the cognitive restructuring in the program based on cognitive-behavioral approach are effective in decreasing both test anxiety and irrational beliefs. Indeed, the cognitive-behavioral approach is regarded as the most effective method in meta-analysis studies on the interventions for test anxiety, which is supportive of this conclusion.

Moreover, the fact that the significant decrease in the levels of test anxiety and irrational beliefs of the adolescents participating in a program for coping with test anxiety based on cognitive-behavioral approach in this study continued to decrease also in follow-up measurements shows that the adolescents can maintain cognitive restructuring and keep on using new knowledge and skills that they learn.

It was seen in this study that the program for coping with test anxiety based on the cognitivebehavioral approach was effective in increasing active coping skills of adolescents. When active coping strategies of the Adolescent Coping Scale is examined, it is seen that the strategies cover cognitive restructuring, problem-solving, emotion regulation, and social support. Thus, it can be said that the program enhances such skills. Additionally, no significant difference was found between pre-test and post-test in the experimental group while there was a significant difference between the experimental and control groups in the avoidant coping subscale. Avoidant coping strategies of the Adolescent Coping Scale include distraction, resignation, social withdrawal, and wishful thinking skills. While avoidant coping strategies of the participating adolescents had a significant decrease compared to the control group, the change in the experimental group was not significant. Therefore, it can be asserted that the program provides awareness in adolescents but should put more emphasis on avoidance strategies. The program based on the cognitivebehavioral approach did not lead to a significant difference in negative coping skills of adolescents. Negative coping strategies of the Adolescent Coping Scale are self-criticism and blaming others. Significantly, the program for coping with test anxiety based on the cognitive-behavioral approach is effective in active and avoidant coping strategies while ineffective in negative strategy. It is suggested that test anxiety programs based on the cognitive-behavioral approach emphasizes problem-solving skills and the importance of cognitive restructuring and thoughts; however, they should put more emphasis on thoughts such as selfcriticism and blaming others. It is also considered essential to highlight strategies of adolescents such as escape, withdrawal, and building confidence. Therefore, it is thought that more activities for negative coping strategies should be given to test anxiety programs based on CBT. At this point, addressing cognitive triad might be effective.

In this study, it was determined that the program to cope with test anxiety based on the cognitivebehavioral approach did not cause a significant difference in the perception levels of academic selfsufficiency of adolescents. Two reasons are attributed to that situation. According to Bandura [19], there are four primary sources of information on the development of the self-efficacy concept. These are past successful performances, modeling, verbal persuasion, and physiological reactions. Although the program includes particularly applications related to physiological reactions, it can be said that the program which is based on the cognitive-behavioral approach is not sufficient in addressing the four sources. Also, Bandura and Locke [39] asserted that the self-efficacy beliefs of individuals were dependent on their past performances. Thus, it seems that addressing previous performances is important in test anxiety programs based on the cognitive-behavioral approach. It can be said that the program can be more effective if past performances of adolescents participating in programs for coping with test anxiety, and their judgments on these performances are addressed. It appears that behaviors are as important as cognitive processes in academic self-efficacy. Moreover, academic self-efficacy of peers can be enhanced by ensuring that they take each other as a model in group studies. It is important to examine an individual's beliefs regarding efficacy expectations for him/her to go into action. Additionally, it should not be ignored that the individuals' beliefs about their academic self-efficacy might be associated with existing cognitive schemas rather than irrational beliefs. Cognitive schemas are the core beliefs of an individual based on early childhood experiences. Schemas are global, generalized, and resistant to change [40]. Interim beliefs and automatic thoughts stem from these schemas, which make an individual's life difficul [41]. Therefore, it is possible that an individual whose core belief is despair might believe that he/she is unsuccessful [40] and accordingly might have low academic self-efficacy belief. This study examined irrational beliefs in the program for coping with test anxiety based on the cognitive-behavioral approach. Hence it is possible to say that the program did not lead to any change in the adolescents' academic self-efficacy perceptions since the schemas were not used. 


\section{CONCLUSION}

As a result, it can be said that coping with test anxiety program based on cognitive-behavioral approach decreases test anxiety levels and irrational beliefs of adolescents; is effective in increasing active coping style and decreasing avoidant coping style; and that it is a long-term effect. On the contrary, it can be said that coping with test anxiety program is not effective in negative coping skills and academic selfefficacy perceptions of adolescents.

Based on the results of this study, it is considered to be important that school psychological counselors working especially with secondary and high school students include test anxiety programs based on the cognitive-behavioral approach in the guidance and psychological counseling services they provide in schools. It can be said that programs which are based on this evidenced approach are efficient in terms of test anxiety problems. As previously stated; especially in the program, it is thought that it is important to include behavioral techniques as much as cognitive components. Additionally, it is considered important to address strategies of escape, withdrawal and ensuring confidence and include the adolescents' past performances and their anticipated outcomes in the process so that coping skills of the students can be enhanced.

There are limitations to this study, which examines the effectiveness of the program to deal with test anxiety based on the cognitive-behavioral approach. The study did not develop a new program for test anxiety and used a revision of an existing program which was based on CBT. In light of the study results, it is thought that the test anxiety program developed based on the cognitive-behavioral approach can be more effective in adolescents.

\section{REFERENCES}

[1] Zeidner, M. Test anxiety: The state of the art. New York: Plenum Press,1998.

[2] Hembree, R. "Correlates, causes, effects, and treatment of test anxiety", Review of Research in Education, vol. 58(1), pp. 47-77, 1988

[3] Aydın, F. "Akademik başarının yordayıcısı olarak akademik güdülenme, öz yeterlilik ve sınav kaygısı (Yayımlanmamış yüksek lisans tezi)," Hacettepe Üniversitesi Sosyal Bilimler Enstitüsü, Ankara, 2010.

[4] Kabalcı, T. "Akademik başarının yordayıcısı olarak benlik saygısı, sınav kaygısı ve sosyo-demografik değişkenler (Yayımlanmamış yüksek lisans tezi)," Hacettepe Üniversitesi Sosyal Bilimler Enstitüsü, Ankara, 2008.

[5] Yıldırım, İ. \& Ergene, T. "Lise son sınıf öğrencilerinin akademik başarılarının yordayıcısı olarak sınav kaygısı, boyun eğici davranışlar ve sosyal destek," Hacettepe Üniversitesi Eğitim Fakültesi Dergisi, vol. 25, pp. 224-234, 2003

[6] Zabun, E. "Dershaneye gitme, mükemmeliyetçilik, ana-baba tutumu ve sınav kaygısının öğrencilerin SBS başarılarını yordama gücü (Yayımlanmamış yüksek lisans tezi)," Gaziosmanpaşa Üniversitesi, Sosyal Bilimler Enstitüsü, Tokat, 2011.

[7] Lowe, P., Lee, S., Witteborg, K., Prichard, K., Luhr, M., Cullinan, C., Mildren, B., Raad, J., Cornelius, R., Janik, M. "Examination of the psychometric properties of a new multidimensional measure of test anxiety among elementary and secondary school student," Journal of Psychoeducational Assesment, vol. 26(3), pp. 215-230, 2008, doi: $10.1177 / 0734282907303760$

[8] Liebert, R. M. \& Morris, L. W. "Cognitive and emotional components of test anxiety: A distinction and some initial data," Psychological Reports, vol. 20, pp. 975-978, 1967. http://dx.doi.org/10.2466/pr0.1967.20.3.975

[9] McDonald, A. S. "The prevalence and effects of test anxiety in school children," Educational Psychology, vol. 21(1), pp. 89-101, 2001, doi: 10.1080/01443410020019867

[10] Türkçapar, H. Bilişsel davranışçı terapi. İstanbul: Epsilon Yayınları, 2018.

[11] Boyacioglu, N. ve Kucuk, L. "Irrational beliefs and test anxiety in Turkish school adolescents," The Journal of School Nursing, vol. 27(64), pp. 47-454, 2011.

[12] Cassady, J.C. \& Johnson, R.E. "Cognitive test anxiety and academic performance," Contemporary Educational Psychology, vol. 27, pp. 270-295, 2002, doi:10.1006/ceps.2001.1094

[13] Demirci, E. "Ergenlerde temel psikolojik ihtiyaçlar irrasyonel inanışları ile mükemmeliyetçilik ve sınav kaygısı arasındaki ilişki. (Yayımlanmamış yüksek lisans tezi)," İstanbul Arel Üniversitesi Sosyal Bilimler Enstitüsü, İstanbul, 2018.

[14] Güler, D. ve Çakır, G. "Lise son sınıf öğrencilerinin sınav kaygısını yordayan değişkenlerin incelenmesi," Türk Psikolojik Danışma ve Rehberlik Dergisi, vol. 4(39), pp. 82-94, 2013.

[15] Ergene, T. "Effective interventions on test anxiety reduction," School Psychology International, vol. 24, pp. 328-332, 2003, doi: 0143-0343 (200211)

[16] Von der Embse, N., Barterian, J. \& Segool, N. "Test anxiety interventions for children and adolescents: a systematic review of treatment studies from 2000-2010," Psychology in the Schools, vol. 50(1), pp. 57-71, 2013, doi: $10.1002 /$ pits. 21660

[17] Spirito, A., Stark, L., Tyc, V. "Stressors and coping strategies described during hospitalization by chronically ill children," Journal of Clinical Child Psychology, vol. 23(3), pp. 314-322, 1994. Doi. 10.1207/s15374424jccp2303_9

[18] Önen, A. "The Impact of Coping Strategies, test anxeity and expectations on the university entrance trail exam scores," (Unpublished Master Thesis). Boğaziçi University Institue of Graduate Social Sciences, 2004. 
[19] Bandura, A. "Self-Efficacy: The Exercise of Control," New York: W. H. Freeman and Company, 1997.

[20] Zimmerman, B. J. "Self Efficacy: an essential motive to learn," Contemporary Educational Psychology, vol. 25(1), pp. 82-91, 2000, Doi: 10.1006/ceps.1999.1016

[21] Güçlü, A. "Eighth grade students' emotion regulation strategies during test taking: The role of gender, cognitive appraisal processes, academic self-efficacy, and test anxiety," Orta Doğu Teknik Üniversitesi, Sosyal Bilimler Enstitüsü, Ankara, 2009.

[22] Büyüköztürk, Ş. "Sosyal bilimler için veri analizi el kitabl," Ankara: Pegem A Yayıncılık, 2007.

[23] Wren, D. G. \& Benson, J. "Measuring test anxiety in children: Scale development and internal construct validation,"Anxiety, Stress \& Coping, vol. 17(3), pp. 227-240, 2004, doi: 10.1080/10615800412331292606

[24] Aydın, U., \& Bulgan, G. "Çocuklarda sınav kaygısı ölçeği'nin Türkçe uyarlaması: geçerlik ve güvenirlik çalışmas1," İlköğretim Online, vol. 16(2), pp. 887-899, 2017, doi: 10.17051/ilkonline.2017.304742

[25] Jinks, J. L., \& Morgan, V. "Children's perceived Academic Self-efficacy. An inventory scale," Eric Clearing House, 1999.

[26] Öncü, H. "Akademik özyeterlik ölçeğinin türkçe’ye uyarlanması," Ahi Evran Üniversitesi Kırşehir Eğitim Fakültesi Dergisi, vol. 13(1), 2012.

[27] Çivitci, A. "Ergenler için mantık dışı inançlar ölçeğinin geliştirilmesi: Geçerlik ve güvenirlik çalışmaları," Türk Psikolojik Danışma ve Rehberlik Dergisi, vol. 3(25), 2016.

[28] Spirito, A., Stark, L. J. ve Williams, C. "Development of a brief coping checklist for use with pediatric populations," Journal of Pediatric Psychology, vol. 13, pp. 555-574, 1988.

[29] Bedel, A., Işı1k, E., \& Hamarta, E. "Ergenler için başa çıkma ölçeğinin (EBÇÖ) geçerlik ve güvenirlik çalışması," Eğitim ve Bilim, vol. 39(176), pp. 227-235, 2014, Doi: 10.15390/EB.2014.3501

[30] Olgun, D. "Uygulamalı Sinav Kaygısı Grup Çalışması," Buca Rehberlik ve Araştırma Merkezi, İzmir.

[31] Borenstein, M., Hedges, L. V., Higgins, J. P., \& Rothstein, H. R. "Introduction to Meta-Analysis," John Wiley \& Sons., 2011.

[32] Cohen, J."Statistical Power Analysis for the Behavioral Sciences," 2nd ed. Hillsdale, New Jersey: Erlbaum, 1988.

[33] Başpınar Can, P., Dereboy, Ç. \& Eskin, M. "Yüksek riskli sınav kaygısının azaltılmasında sistematik duyarsızlaştırma ile bilişsel yeniden yapılandırmanın etkililiğinin karşılaştırılması," Türk Psikiyatri Dergisi, vol. 23(1), pp. 9-17, 2012.

[34] Bozanoğlu, İ. "Bilişsel davranışçı yaklaşıma dayalı grup rehberliğinin güdülenme, benlik saygısı, başarı ve sınav kaygısı düzeylerine etkisi," Ankara Üniversitesi Ĕ̆itim Bilimleri Fakültesi Dergisi, vol. 38(1), pp. 17-42, 2005.

[35] Demirci, İ., \& Erden, S. "Bilişsel davranışçı yaklaşıma dayalı grupla psikolojik danışma uygulamasının 8. sınıf öğrencilerinin sınav kaygısına etkis," Marmara Üniversitesi Atatürk Eğitim Fakültesi Eğitim Bilimleri Dergisi, vol. 43(43), pp. 67-83, 2016, Doi: 10.15285/ebd.51646

[36] Tenenbaum, Laura S., "A school-based intervention for third grade students experiencing test anxiety." dissertation," Georgia State University, 2012, Retrieved from https://scholarworks.gsu.edu/cps_diss/69

[37] Yavuzer, Y., Gündoğdu, R., \& Dikici, A. "Yaratıcı drama temelli grup rehberliği ve bilişsel-davranışçı yaklaşıma dayalı grupla psikolojik danışmanın ergenlerin kaygı düzeylerine etkileri," e-Journal of New World Sciences Academy, vol. 5(3), pp. 1026-1040, 2010.

[38] Ulusoy, S., Yavuz, K. F., Esen, F. B., Umut, G., \& Karatepe, H. T. "Sınav kaygısına yönelik bilişsel grup terapisi," Bilişsel Davranışçı Psikoterapi ve Araştırmalar Dergisi, vol. 1, pp. 28-37, 2016, Doi: 10.5455/JCBPR. 212133

[39] Bandura, A., \& Locke, E. A. "Negative self-efficacy and goal effects revisited," Journal of applied psychology, vol. 88(1), pp. 87-99, 2003, Doi: 10.1037/0021-9010.88.1.87

[40] Beck, J. S. "Bilişsel terapi: Temel ilkeler ve ötesi," Çev. Hisli Şahin, N. Türk Psikologlar Derneği Yayınları, Ankara, 2001.

[41] Sharf, R. S. "Psikoterapi ve psikolojik danışma kuramları," Nobel Yayınları, Ankara, 2014. 